Sains Malaysiana 49(2)(2020): 421-427

http://dx.doi.org/10.17576/jsm-2020-4902-21

\title{
Constant Disturbance in Critical Care Units Influenced Patients' Sleep Quality
}

(Gangguan Berterusan di Unit Penjagaan Kritikal Mempengaruhi Kualiti Tidur Pesakit)

\author{
Zainah Mohamed*, Gurbinder Kaur Jit Singh, Aishairma Aris, Nur Aishah Awang Maharum \\ \& LALITHA VELAYOM
}

\begin{abstract}
The critically ill patients' experiences and sleep quality are a crucial aspect of quality care in the critical care setting. The aim of this study was to identify the perceived sleep quality and patients' experiences during their stay in critical care units. Data was collected using validated and reliable self-reported questionnaires by patients on sleep quality in the intensive care unit and intensive care experience (ICEQ) for two months'duration. A random sampling was used in participants'selection and 55 patients who fulfilled the inclusion criteria participated in this study. Descriptive and Inferential analyses were used in data analysis. Mean age of the respondents was 52 with 64\% male. More than half (58.2\%) patients reported poor sleep quality while in critical care units. Disruption in patients'sleep was mainly due to noises from medical devices alarms (76.36\%) and constantly taking vital signs e.g. measuring blood pressure (70.90\%). Even though more than half of the patients (54.5\%) reported more frightening experiences while in critical care units, but overall their experience was either positive or neutral. Patients (16.36\%) who stayed longer in critical care units between 8-12 days reported better sleep quality. Reducing noise by minimizing the alarm sounds and attend to any alarm as soon as possible may help to promote better outcome for patients'sleep quality and experience while in critical care. It is important for nurses to plan and cluster the patient's care to avoid constant disturbance.
\end{abstract}

Keywords: Critical care; environment; life change events; patients; sleep deprivation

\section{ABSTRAK}

Pengalaman dan kualiti tidur adalah aspek penjagaan yang penting dalam penjagaan pesakit di unit kritikal. Tujuan kajian ini adalah untuk mengenal pasti kualiti tidur dan pengalaman pesakit yang dialami semasa mereka berada di unit penjagaan kritikal. Data dikumpulkan daripada pesakit selama dua bulan dengan menggunakan soal selidik sleep quality in the intensive care unit and intensive care experience (ICEQ). Pensampelan secara rawak digunakan dalam pemilihan responden dan 55 pesakit yang memenuhi kriteria rangkuman terlibat dalam kajian ini. Analisis deskriptif dan Inferensial digunakan dalam analisis data. Min umur responden adalah 52 tahun dengan 64\% adalah lelaki. Majoriti pesakit (78.2\%) tinggal selama sekurang-kurangnya lima hari dalam unit penjagaan kritikal. Lebih separuh (58.2\%) pesakit melaporkan kualiti tidur yang kurang baik dalam unit penjagaan kritikal. Gangguan tidur pada pesakit terutamanya disebabkan bunyi daripada penggera peranti perubatan (76.36\%) dan sentiasa mengambil tanda-tanda vital, contohnya mengukur tekanan darah (70.90\%). Walaupun lebih separuh daripada pesakit (54.5\%) melaporkan lebih banyak pengalaman yang menakutkan semasa berada dalam unit penjagaan kritikal, tetapi secara keseluruhan mereka mengkelaskan pengalaman mereka sebagai positif atau neutral. Pesakit (16.36\%) yang tinggal lebih lama dalam unit penjagaan kritikal antara 8-12 hari melaporkan kualiti tidur yang lebih baik pada hari-hari akhir mereka dirawat di unit kritikal. Pengurangan bunyi bising dengan meminimumkan bunyi penggera dan hadir segera kepada mana-mana penggera dengan secepat mungkin boleh membantu mempromosikan tidur yang lebih berkualiti kepada pesakit unit rawatan kritikal. Adalah penting untuk jururawat merancang dan mengelompokkan penjagaan pesakit untuk mengelakkan gangguan yang berterusan.

Kata kunci: Gangguan tidur; pesakit; persekitaran; perubahan gaya hidup; rawatan kritikal

\section{INTRODUCTION}

Every year, thousands of people need to be cared for in critical care units due to critical illness or other injuries. Patients admitted to critical care units usually present with unexpected life threatening condition (Granja et al. 2005; Karlsson et al. 2012) which is often acute with many of them struggle to survive (Johansson et al. 2012). The environment in the critical care unit can be described as a state of suffering of the patients due to the heavy usage of medical instruments, intense treatment the patients receive, and busiest nursing care activities (Fatima et al. 2016; Kamdar et al. 2012). A direct connection between illness and environment will lead to not only post-traumatic psychological problems, but also physical disability (Elbaz et al. 2017; Merilainen et al. 2010). Patients' emotional experience related to real events in critical care units can lead to various degrees of anxiety and depression which can delay and impact 
their recovery process (Granja et al. 2005; Rattray et al. 2010).

The patients' experiences can be categorised as positive, negative or neutral experiences that are recalled by patients (Hofhuis et al. 2008; Samuelson 2011). Demographic factors such as age and gender have been identified to have a relationship with the patients' experiences. Female patients were more likely to have higher frightening experience than male patients (Fatima et al. 2016) and younger patients scored high in frightening experience of being in critical care unit (Rattray et al. 2010; Zhang et al. 2014).

Hospitalized patients, particularly those who are critically ill, are known to have severe sleep fragmentation and disturbed sleep (Medic et al. 2017; Mohsen et al. 2015). In fact, sleep deprivation is a common issue faced by the patients in the critical care setting with detrimental physiological and behavioral consequences (Johansson et al. 2012). Patients' poor sleep quality was contributed by the environment in critical care units and patients' related factors such as medical conditions and psychological problems (Bano et al. 2014; Kamdar et al. 2012). Currently, there are not many similar studies conducted in Malaysia. The aim of this study was to evaluate the quality of patients' sleep while in critical care units and to identify their experiences while in critical care units in regards to awareness of surrounding, frightening experiences, and recall of experiences. This study was also examined the relationship between patient's demographic data and their quality of sleep.

\section{MATERIALS AND METHODS}

\section{STUDY DESIGN AND SUBJECTS}

The present study cross-sectional study was conducted from April till June 2018 at a university hospital in Kuala Lumpur, Malaysia. Convenience sampling method was used to select samples for the study. Based on the Krejcie and Morgan's (1970) formula, a total sample of 169 was needed for this study. Patients admitted to the critical care unit for at least two nights were approached within $24 \mathrm{~h}$ after they had been transferred out to the ordinary ward. Those who had any mental illness based on their medical report and those who work as health care personnel were excluded from the study.

\section{RESEARCH TOOLS AND MATERIALS}

\section{The Intensive Care Experience Questionnaire (ICEQ)}

Patients' experience in the critical care unit in this study was assessed using the ICEQ developed by Rattray (2004). The ICEQ is a validated and reliable questionnaire which consists of 24 items clustered into four subscales: awareness of surrounding ( 9 items), frightening experience (6 items), recall of experience ( 5 items) and satisfaction with care (4 items). All items measure levels of agreement on Likert scale of 1 to 5 in which 1 indicates 'strongly disagree' and 5 indicates 'strongly agree' and the scores for each subscale were totalled up. The subscale of awareness of surrounding, frightening experiences, and recall of experiences and satisfaction with care had a good reliability of $\alpha 0.83, \alpha 0.67, \alpha 0.67$ and $\alpha 0.95$, respectively. In addition, the categories of each item were collapsed into three; Agreeable, Neither and Disagreeable.

\section{THE SLEEP IN THE ICU QUESTIONNAIRE}

The sleep ICU questionnaire consists of 27 items. All items used a 10-point Likert scale. Two items measure the rate of overall quality of sleep on Likert scale of 1 to 10 where 1 indicates 'poor' and 10 indicates 'excellent'. Another three items measure the sleep quality on the first day, middle and end stay in ICU as 1 to indicate 'no sleep' while 10 indicates 'excellent'. Four items measure the degree of daytime sleepiness (overall, first night, middle and end stay) in ICU which 1 indicates 'unable to stay awake' and 10 indicates 'fully alert and awake'. The remaining 18 items measure sleep disruption (environmental stimuli 7 items and noises 11 items) in ICU with 1 indicates 'no disruption' and 10 indicates 'significant disruption'. In the present study, each item of the quality of sleep and daytime sleepiness was categorized into two (poor sleep quality vs. good sleep quality) while each of sleep disruption item was grouped into 'no disruption' vs. 'significant disruption'.

\section{DATA ANALYSIS}

Data analysis was performed using SPSS IBM version 23.0 (Statistical Package for the Social Sciences, IBM Corp., Armonk, NY, USA). Data were entered, reviewed for errors and cleaned prior to the analysis. Descriptive analysis was used to identify the frequency, percentage, mean and standard deviation of the demographic variables, quality of sleep and patients' experiences. The continuous variables for patient's experience and sleep quality were tested for normality using the Kolmogorov Smirnov test and it was found to be normally distributed. Therefore, parametric tests (ANOVA and t-Test) were used for the inferential analyses to examine the relationship between patients' demographic variables and their quality of sleep and experiences during their stay in critical care units. Statistical significance was set at $\mathrm{p}<0.05$.

\section{RESULTS}

\section{SOCIODEMOGRAPHIC DATA}

A total of 55 patients (response rate $=32.5 \%$ ) had participated in the study. The low response rate was due to many factors: refused to participate $(38.5 \%)$, had persistent non-orientated status $(5.9 \%)$, transferred out to other hospitals (2.4\%) and discharged home (20.7\%). Majority of the participants' ethnicity were Malays 
(61.8\%), followed by Chinese (25.5\%), Indians (9.1\%), and others $(3.6 \%)$. The mean age of the participants was $52.04 \pm 18.98$ years with the participants being predominantly male $(63.6 \%)$. The length of stay in critical care units ranged from 3 to 22 days (mean $=5.67, \mathrm{SD}=$ 2.99). A high proportion of the participants $(n=43,78.18 \%)$ stayed in ICUs for three to seven days whilst $11(20 \%)$ of them stayed in ICUs for eight to 12 days and only one $(1.8 \%)$ participant stayed for $18-22$ days. On the other hand, none of them (0\%) stayed for 13-17 days.

\section{SLEEP QUALITY}

Majority patients had a good sleep quality at home $(n=46$, $83.6 \%$,) as compared to while in critical care unit where more than half of the patients $(n=32,58.2 \%$, ) in this study reported poor quality of sleep. However, the patients' sleep quality improved overtime during their stay in critical care units. During the first night at critical care unit, more than half $(n=33,60 \%$ ) reported having poor sleep quality. The number of patients reported poor sleep quality drop to $\mathrm{n}=27$ $(49.1 \%)$ and further reduced to only $20(36.4 \%)$ during their end of their stay in the critical care unit. To see the impact of length of stay on sleep quality while in critical care unit, the categories of the length of stay were collapsed into two groups (Group 1: 3 - 7 days; Group 2: $8-22$ days). Using the independent $t$ test, there was no statistically significant difference in the sleep quality between group 1 (Mean=6.26, $\mathrm{SD}=2.05)$ and 2 of length of stay $(\mathrm{Mean}=6.33, \mathrm{SD}=1.56) ; \mathrm{t}=-.121,(\mathrm{p}>0.05)$. The level of significance was also not achieved $(p>0.05)$ for all the relationship between demographic data (age, gender, ethnicity) towards patients' sleep quality.

Disruption in patients' sleep was mainly due to environmental noise and environmental activities (Table 1). For the environmental noise, alarm of the medical devices such as ventilator, cardiac monitor, pulse oximeter, and I.V pump was seen as the main contributor to poor sleep $(76.4 \%)$ among the critically ill patients. As for the environmental activities, checking vital signs (70.9\%) was rated as the significant contributors to poor sleep quality among critical care patients. The second highest environmental factors affected patients' sleep quality was performing diagnostic test $(67.3 \%)$, followed by taking blood samples (63.6\%). Administration of medications was rated as the least significant factors affecting sleep quality $(56.4 \%)$.

\section{PATIENT'S EXPERIENCE}

Many patients $(89.1 \%)$ were aware of their surroundings. Majority (74.5\%) of the patients agreed that they knew of them being nursed in critical care units. Majority (76.4\%) of the patients also agreed to the statement of them being able to recognise their relatives, remember their relatives being with them $(78.2 \%)$ and aware of someone's presence near them $(72.7 \%)$. A large number $(81.8 \%)$ of patients felt safe and in control (74.5\%) while in critical care units (Table 2).

Many patients $(54.5 \%)$ reported more frightening experiences while in critical care units and their frightening experiences were related to the feeling of helplessness $(56.4 \%)$ and in pain $(52.7 \%)$. Even though the thought of dying $(23.6 \%)$, feeling scared $(36.3 \%)$ and having bad dreams $(18.2 \%)$ were also reported by some patients as causes of their frightening experiences, the majority of the patients viewed these factors as insignificant in contributing to their frightening experiences as the majority of patients disagreed to these statements as shown in Table 3. Patients do not have problem in recalling their experiences (Table 4) during their stay in critical care units as more than half $(54.5 \%)$ of them have high recall capability. Almost half of the patients $(49.1 \%)$ were disagreeable to the statement that most of their memories were blurred. Majority (58.2\%) of the patients tend to sleep more, knew what day and night $(40.0 \%)$ and knew what was happening to them (38.2\%). The level of significant was not achieved between each type of experience with length of stay groups $(p>0.05)$.

TABLE 1. Perceived sleep disruption in critical care unit

\begin{tabular}{lcc}
\hline Items & No disruption & Response \\
& $\mathrm{n}(\%)$ & $\begin{array}{c}\text { Significant disruption } \\
\mathrm{n}(\%)\end{array}$ \\
\hline Environmental noises & & \\
Medical devices alarm & $13(23.6)$ & $42(76.4)$ \\
Suctioning & $38(69.1)$ & $17(30.9)$ \\
Talking & $48(87.3)$ & $7(12.7)$ \\
Telephone & $54(98.2)$ & $1(1.8)$ \\
Environmental activities & & $39(70.9)$ \\
Taking vital signs e.g. measuring blood pressure & $16(29.1)$ & $37(67.3)$ \\
Diagnostic test e.g. x-ray & $18(32.7)$ & $35(63.6)$ \\
Taking blood samples & $20(36.4)$ & $31(56.4)$ \\
Administration of medications & $24(43.6)$ & \\
\hline
\end{tabular}


TABLE 2. Patients' experiences in regards to awareness of surrounding

\begin{tabular}{|c|c|c|c|}
\hline \multirow[b]{2}{*}{ Items } & \multicolumn{3}{|c|}{ Response } \\
\hline & $\begin{array}{c}\text { Agreeable } \\
\text { n (\%) }\end{array}$ & $\begin{array}{c}\text { Neither } \\
\mathrm{n}(\%)\end{array}$ & $\begin{array}{c}\text { Disagreeable } \\
\mathrm{n}(\%)\end{array}$ \\
\hline I recognized my relatives & $42(76.4)$ & $2(3.6)$ & $11(20.0)$ \\
\hline I was aware of someone near to me & $40(72.7)$ & $3(5.5)$ & $12(21.8)$ \\
\hline I knew where I was & $41(74.5)$ & $6(10.9)$ & $8(14.6)$ \\
\hline I knew what was happening to me & $35(63.6)$ & $10(18.2)$ & $10(18.2)$ \\
\hline I remember my relatives being with me & $43(78.2)$ & $6(10.9)$ & $6(10.9)$ \\
\hline I felt safe & $45(81.8)$ & $5(9.1)$ & $5(9.1)$ \\
\hline I felt in control & $41(74.5)$ & $3(5.5)$ & $11(20.0)$ \\
\hline I was able to let people know what I wanted & $33(60.0)$ & $11(20.0)$ & $11(20.0)$ \\
\hline I have no recollection of being in Critical Care Units & $16(29.1)$ & $10(18.2)$ & $29(52.7)$ \\
\hline
\end{tabular}

TABLE 3. Patients' experiences in regards to frightening experiences

\begin{tabular}{lccc}
\hline Items & Agreeable & Response & Disagreeable \\
& $\mathrm{n}(\%)$ & $\mathrm{Neither}$ & $\mathrm{n}(\%)$ \\
\hline I seemed to have bad dreams & $10(18.2)$ & $5(9.1)$ & $40(72.7)$ \\
I felt scared & $20(36.3)$ & $4(7.3)$ & $31(56.4)$ \\
I saw strange things & $9(16.3)$ & $3(5.5)$ & $43(78.2)$ \\
I felt helpless & $31(56.4)$ & $11(20.0)$ & $13(23.6)$ \\
I thought I would die & $13(23.6)$ & $6(10.9)$ & $36(65.5)$ \\
I seemed to be in pain & $29(52.7)$ & $15(27.3)$ & $11(20.0)$ \\
\hline
\end{tabular}

TABLE 4. Patients' experiences in regards to recall of experiences

\begin{tabular}{|c|c|c|c|}
\hline \multirow[t]{2}{*}{ Items } & \multicolumn{3}{|c|}{ Response } \\
\hline & $\begin{array}{c}\text { Agreeable } \\
\text { n (\%) }\end{array}$ & $\begin{array}{c}\text { Neither } \\
\text { n }(\%)\end{array}$ & $\begin{array}{c}\text { Disagreeable } \\
\mathrm{n}(\%)\end{array}$ \\
\hline I wish I remembered more about it & $25(45.5)$ & $7(12.7)$ & $23(41.8)$ \\
\hline Most of my memories are blurred & $20(36.4)$ & $8(14.5)$ & $27(49.1)$ \\
\hline I wish I had known more about what was happening to me & $21(38.2)$ & $7(12.7)$ & $27(49.1)$ \\
\hline I seemed to sleep too much & $32(58.2)$ & $8(14.5)$ & $15(27.3)$ \\
\hline I never knew whether it was day or night & $22(40.0)$ & $7(12.7)$ & $26(47.3)$ \\
\hline I seemed to be in pain & $29(52.7)$ & $15(27.3)$ & $11(20.0)$ \\
\hline
\end{tabular}

\section{DISCUSSION}

Sleep disruption is common among hospitalized patients. No matter how intense the ward is, the patient admitted that their sleep quality is reduced during their stay in the hospital (Wesselius et al. 2018) compared to while at home, and became more significant when patients were admitted in critical care units (Cicek et al. 2014; Mohsen et al. 2015). In our study, even though the majority of the patients $(58.2 \%)$ reported having disruption to sleep, their quality of sleep noticeably improved from the first day until the end of their stay in critical care units. This finding is parallel with previous studies where they found that patients' sleep quality improved just before the patients were transferred out from the intensive care unit (Cicek et al. 2014).

Hospitalised patients encounter many internal and environmental problems in terms of trying to suits themselves with unfamiliar environment and surroundings. Patients' experience and sleep quality in critical care settings contribute significantly towards patients' health (Besedovsky et al. 2012; Kamdar et al. 2012). In our study, the most sleep destructive environmental noises were the medical devices alarms. The medical devices alarms in this study includes cardiac monitors, ventilators, and infusion devices. This finding is in line with Mohsen et 
al.'s (2015) finding in which $94.2 \%$ of patients attributed their sleep disturbance to noises from devices and connection in the body. Likewise, Fanfulla et al.'s (2011) result showed patients' arousals from sleep during the day and night were due to noises, even though the level of noise during night is lower than daytime.

With advancement of technology, the use of auditory alarmed equipment in critical care unit helps to alert health care professionals quicker towards patients' condition and act accordingly. It has been reported that the medical devices alarms are significantly responsible for the environmental noise (Mohammad \& Hayajneh 2018). In the current study, alarm of the medical devices was reported as the major contributor to poor patients' sleep. This finding is quite alarming as sleep disruptions due to medical devices is something that can be manipulated. The alarm can be taken under control by training and changing behaviour of the health care professionals (Fontana \& Pittiglio 2010; Pulak \& Jensen 2016), as the cause of the sleep disruption was mostly related to modifiable factors (Cicek et al. 2014; Hofhuis et al. 2008; Mohsen et al. 2015). In our study, phone sounds disrupted the patients' sleep the least $(1.8 \%)$. The setting where this study was conducted had policy that no hand phone should be brought near the patients' area. The ward phone was at the nursing counter which was located quite far from the patients' area.

In our study, we determined that the disruptive environmental activities came from many factors. Taking vital signs $(70.9 \%)$ was reported in the current study to be one of the most disruptive activities. This finding was similar to the study carried out by Tastan et al. (2010) where $75 \%$ of their patients reported the reason for sleep disruption was due to continuous blood pressure measurements. The other activities in our study that rated higher than $50 \%$ were diagnostic testing $(67.3 \%)$, taking blood samples $(63.6 \%)$ and administration of medication (56.4\%). These findings of other common sleep destructive activities were also supported by other studies where they found light, nursing interventions, collecting blood samples, taking vital signs and diagnostic testing were the contributing factors to poor sleep quality (Hofhuis et al. 2008; Little et al. 2012; Mohsen et al. 2015; RitmalaCastren et al. 2015).

Even though administration of medication was the least reported reason for sleep disruption in our study, the rate of $56.4 \%$ was still consider as high disruption. Tastan et al. (2010) also reported that $95 \%$ of their patients' sleep were disrupted due to medication procedures. Similarly, Ritmala-Castren et al. (2015) also found that administering medication was the most factor affecting patients' quality of sleep. In contrast, in the study conducted by Cicek et al. (2014), administering medication was found to be a less common factor disrupting sleep compared to the other environmental activities. This might due to proper arrangement of nursing care where nurses cluster their nursing care to maximize the patient's rest and sleep pattern.

\section{PATIENTS' EXPERIENCES}

In regards to patients' experience in critical care units, our findings showed that it was similar among different age groups, gender, ethnicity, and length of stay. This finding was supported by one study that reported patients frightening experiences were similar among different demographic data (Alasad et al. 2015). Majority of the patients in our study were aware of their surroundings. They knew of their whereabouts, they can remember being in critical care units, they were able to recognize their relatives, remember their relatives being with them and were aware of someone's presence near them.

Previous study has reported that the highest percentage of patients disagree to the statement of not having recollection of being in the intensive care unit (Alasad et al. 2015). The finding was parallel with the current study where majority of the patients did not have problems in recalling their experiences during their stay in critical care units. Patients reported that they knew day and night, and knew what was happening to them. In contrast, another study has reported that patients were found to have either no or little memories of staying in ICU. Patients reported having blurred memories most of the time and majority of them tend to sleep more (Hofhuis et al. 2008). Many patients could not recall when is day and night, could not sleep much and rarely knew what was happening to them during their stay in ICU (Rattray et al. 2010).

In the current study, a large number of patients also felt safe and in control while in critical care units. These results are to some extent comparable to other findings in terms of feeling safe (Rattray et al. 2010). However, even though patients feel safe, they do not feel in control while in intensive care unit (Medic et al. 2017; Rattray et al. 2010). This was parallel with our current patients' frightening experiences where they reported the feeling of helplessness. Even though it is not a major factor, the thought of dying, feeling scared and having bad dreams were also reported by some patients in our study. These findings were supported by Alasad et al. (2015) who found that thought of dying and having bad dreams was not a major contributing factors to frightening experiences to majority of their patients.

As it is taken into consideration that a sufficient and quality sleep will improve the recovery of patients receiving care in critical care unit, protected time to ensure sleep and rest need to be provided to the patients. All health care providers need to be informed about the importance and the necessity of sleep to heighten up the healing process of the critically ill patients.

Some limitations in the study should be considered. The results of the study are limited to one single setting only, which implies the experiences of patients from the other setting will be different. The severity of the disease and the effect of medical treatment that can affect their sleep quality and critical care experiences were not compared. The data were collected while the patients were still in the hospital and their perceptions may have been 
influenced by the fact that they had not physically recovered completely or still having some effect from the influence of medications on recall.

\section{CONCLUSION}

In conclusion, the findings of this study indicates that patients' sleep disturbance while nursed in critical care were mainly related to environmental noise which came from medical devices alarm and constant disturbance from the environmental activities. Reducing noise by minimizing the alarm sounds and attend to any alarm as soon as possible will help to promote better outcome for patients' sleep quality and experience while in critical care. For constant disturbance, it is important for nurses to plan and cluster the patient's care. Nurses should speak if they feel that the other health care team members are not considering the patient's needs.

\section{ACKNOWLEDGEMENTS}

The authors would like to acknowledge the participants who participated in this study and spend their valuable time in answering the questionnaires. The authors would also like to acknowledge the director and staff of the participating hospitals that allowed the study to be conducted.

\section{REFERENCES}

Alasad, A., Tabar, A. \& Ahmad, M. 2015. Patients' experience of being in intensive care units. Journal of Critical Care 30(4): 859.e7-859.e11.

Bano, M., Chiaromanni, F., Corrias, M., Turco, M., De Rui, M., Amodio, P., Merkel, C., Gatta, A., Mazzotta, G., Costa, R. \& Montagnese, S. 2014. The influence of environmental factors on sleep quality in hospitalized medical patients. Frontiers in Neurology 5: 267.

Besedovsky, L., Lange, T. \& Born, J. 2012. Sleep and immune function. European Journal of Physiology 463(1): 121-137.

Cicek, H., Armutcu, B., Yava, A., Tosun, N. \& Celik, T. 2014. Sleep quality of patients hospitalized in the coronary care unit and of the affecting factors. Intensive Care Medicine 7(1): 324-330.

Elbaz, M., Leger, D., Sauvet, F., Champigneulle, B., Rio, S., Strauss, M., Chennaoui, M., Guilleminault, C. \& Mira, J.P. 2017. Sound level intensity severely disrupts sleep in ventilated ICU patients throughout a $24-\mathrm{h}$ period: A preliminary $24 \mathrm{~h}$ study of sleep stages and associated sound levels. Annals of Intensive Care 7: 25.

Fanfulla, F., Ceriana, P., Lupo, N.D., Trentin, R., Frigerio, F. \& Nava, S. 2011. Sleep disturbances in patients admitted to a step-down unit after ICU Discharge: The role of mechanical ventilation. Sleep 34 (3): 355-362.

Fatima, Y., Doi, R., Najman, M. \& Mamun, A. 2016. Exploring gender difference in sleep quality of young adults: Findings from a large population study. Clinical Medicine \& Research 14(3-4): 138-144

Fontana, C.J. \& Pittiglio, L.I. 2010. Sleep deprivation among critical care patients. Critical Care Nursing Quarterly 33(1): 75-81.
Granja, C., Lopes, A., Moreira, S., Dias, C., Costa-Pereira, A. \& Carneiro, A. 2005. Patients' recollections of experiences in the intensive care unit may affect their quality of life. Critical Care 9(2): 96-109.

Hofhuis, M., Spronk, E., Van Stel, F., Schrijvers, P., Rommes, H. \& Bakker, J. 2008. Experiences of critically ill patients in the ICU. Intensive and Critical Care Nursing 24(5): 300313.

Johansson, L., Bergbom, I. \& Lindahl, B. 2012. Meaning of being critically ill in a sound intensive ICU patient room-A phenomenological hermeneutical study. The Open Nursing Journal 6: 108-116.

Kamdar, B., Needham, M. \& Collop, A. 2012. Sleep deprivation in critical illness. Journal of Intensive Care Medicine 27(2): 97-111.

Karlsson, V., Bergbom, I. \& Forsberg, A. 2012. The lived experiences of adult intensive care patients who were conscious during mechanical ventilation: A phenomenological-hermeneutic study. Intensive and Critical Care Nursing 28(1): 6-15.

Krejcie, R.V. \& Morgan, D.W. 1970. Determining sample size for research activities. Educational \& Psychological Measurement 30: 607-610.

Little, A., Ethier, C., Ayas, N., Thanachayanont, T., Jiang, D. \& Mehta, S. 2012. A patient survey of sleep quality in the intensive care unit. Minerva Anestesiologica 78(4): 406414.

Medic, G., Wille, M. \& Hemels, H. 2017. Short- and longterm health consequences of sleep disruption. Nature and Science of Sleep 9: 151-161.

Meriläinen, M., Kyngäs, H. \& Ala-Kokko, T. 2010. 24-hour intensive care: An observational study of an environment and events. Intensive and Critical Care Nursing 26(5): 246253.

Mohammad, B.Y. \& Hayajneh, F.A. 2018. Quality of sleep among intensive care unit patients. Critical Care Nursing Quarterly 41(2): 170-177.

Mohsen, M.E., El-Aziz, M.A., Almezaien, M. \& Sobh, D.E. 2015. Factors associated with sleep pattern disturbance among patients in critical care units. Journal of Nursing and Health Science 4(2): 2320-1940.

Pulak, L.M. \& Jensen, L. 2016. Sleep in the intensice care unit: A review. Journal of Intensive Care Medicine 31(1): 14-23.

Rattray, J., Crocker, C., Jones, M. \& Connaghan, J. 2010. Patients' perceptions of an emotional outcome after intensive care: Results from a multicenter study. Nursing in Critical Care 15(2): 86-93.

Rattray, J., Johnston, M. \& Wildsmith, W. 2004. The intensive care experience: Development of the ICE questionnaire. Journal of Advanced Nursing 47(1): 6473.

Ritmala-Castren, M., Virtanen, I., Leivo, S., Kaukonene K.M. \& Leino-Kilpi, H. 2015. Sleep and nursing care activities in an intensive care unit. Nursing \& Health Sciences 17: 354-361.

Samuelson, K.A.M. 2011. Unpleasant and pleasant memories of intensive care in adult mechanically ventilated patients - findings from 250 interviews. Intensive and Critical Care Nursing 27(2): 76-84.

Tastan, S., Unver, V., Iyigun, E. \& Iyisoy, A. 2010. Study on effects of intensive care environment on sleep state of patients. Anatolian Journal of Clinical Investigation 4(1): 5-10. 
Wesselius, H.M., van den Ende, E.S., Alsma, J., ter Maaten, J.C., Schuit, S.C.E., Stassen, P.M., de Vries, O.J., Kaasjager, K.H.A.H., Haak, H.R., van Doormaal, F.F., Hoogerwerf, J.J., Terwee, C.B., van de Ven, P.M., Bosch, F.H., van Someren, E.J.W. \& Nanayakkara, P.W.B., for the 'Onderzoeks Consortium Acute Geneeskunde' Acute Medicine Research Consortium. 2018. Quality and quantity of sleep and factors associated with sleep disturbance in hospitalized patients. JAMA Internal Medicine 178(9): 1201-1208.

Zhang, S., Chang, C., Zhang, J., Song, B., Fang, H. \& Xu, Y. 2014. Correlation analysis of sleep quality and youth ischemic stroke. Behavioral Neurology 2014(246841): $1-14$.
Department of Nursing

Pusat Perubatan Universiti Kebangsaan Malaysia

Jalan Yaacob Latif, Bandar Tun Razak

56000 Kuala Lumpur, Federal Territory

Malaysia

*Corresponding author; email: zaizan@ppukm.ukm.edu.my

Received: 11 May 2019

Accepted: 30 October 2019 
